University of Nebraska - Lincoln

DigitalCommons@University of Nebraska - Lincoln

Michigan Bovine Tuberculosis Bibliography and

Database

Wildlife Disease and Zoonotics

1998

\title{
Mycobacterium bovis in Coyotes from Michigan
}

Colleen S. Bruning-Fann

Stephen M. Schmitt

Scott D. Fitzgerald

Janet B. Payeur

Diana L. Whipple

See next page for additional authors

Follow this and additional works at: https://digitalcommons.unl.edu/michbovinetb

Part of the Veterinary Medicine Commons

Bruning-Fann, Colleen S.; Schmitt, Stephen M.; Fitzgerald, Scott D.; Payeur, Janet B.; Whipple, Diana L.; Cooley, Thomas M.; Carlson, Thomas; and Friedrich, Paul, "Mycobacterium bovis in Coyotes from Michigan" (1998). Michigan Bovine Tuberculosis Bibliography and Database. 22.

https://digitalcommons.unl.edu/michbovinetb/22

This Article is brought to you for free and open access by the Wildlife Disease and Zoonotics at DigitalCommons@University of Nebraska - Lincoln. It has been accepted for inclusion in Michigan Bovine Tuberculosis Bibliography and Database by an authorized administrator of DigitalCommons@University of Nebraska Lincoln. 


\section{Authors}

Colleen S. Bruning-Fann, Stephen M. Schmitt, Scott D. Fitzgerald, Janet B. Payeur, Diana L. Whipple, Thomas M. Cooley, Thomas Carlson, and Paul Friedrich 


\section{Mycobacterium bovis in Coyotes from Michigan}

Colleen S. Bruning-Fann,' Stephen M. Schmitt, ${ }^{2}$ Scott D. Fitzgerald, ${ }^{3}$ Janet B. Payeur, ${ }^{4}$ Diana L. Whipple, ${ }^{5}$ Thomas M. Cooley, ${ }^{2}$ Thomas Carlson, ${ }^{6}$ and Paul Friedrich, ${ }^{2}$ Veterinary Services, Animal and Plant Health Inspection Service, United States Department of Agriculture, Holt, Michigan 48842, USA; ${ }^{2}$ Wildlife Disease Laboratory, Rose Lake Wildlife Research Station, Michigan Department of Natural Resources, East Lansing, Michigan 48823, USA; ${ }^{3}$ Animal Health Diagnostic Laboratory and Department of Pathology, College of Veterinary Medicine, Michigan State University, East Lansing, Michigan 48824, USA; ${ }^{4}$ National Veterinary Services Laboratories, United States Department of Agriculture, Ames, lowa 50010, USA; ${ }^{5}$ Agricultural Research Service, United States Department of Agriculture, Ames, lowa 50010, USA; and ${ }^{6}$ Atlanta Field Office, Wildlife Division, Michigan Department of Natural Resources, Atlanta, Michigan 49709, USA

ABSTRACT: During a survey for tuberculosis in wild carnivores and omnivores, Mycobacterium bovis was cultured from pooled lymph nodes of three adult female coyotes (Canis latrans) harvested by hunters in Michigan (USA). No gross or histologic lesions suggestive of tuberculosis were seen in these animals. One coyote was taken from Montmorency county and two coyotes from Alcona county located in the northeastern portion of Michigan's Lower Peninsula where free-ranging white-tailed deer (Odocoileus virginianus) have been found infected with bovine tuberculosis. It is thought that these coyotes became infected with $\boldsymbol{M}$. bovis through the consumption of tuberculous deer. Other species included in the survey were the opossum (Didelphis virginiana), raccoon (Procyon lotor), red fox (Vulpes vulpes), bobcat (Felis rufus), and badger (Taxidea taxus).

Key words: Case report, coyote, Canis latrans, Mycobacterium bovis, survey, tuberculosis.

Mycobacterium bovis, the causative agent of bovine tuberculosis, is known to infect many domestic and wildlife species (Francis, 1958). Most cases of tuberculosis in wildlife are sporadic and occur primarily as a result of the spillover of infection from domesticated species that are infected with $M$. bovis. However, wildlife have been implicated as a reservoir for tuberculosis in New Zealand, England, and Ireland (Nolan and Wilesmith, 1994; Patterson et al., 1995; Sauter and Morris, 1995). In 1995, bovine tuberculosis was discovered to be endemic in free-ranging whitetailed deer (Odocoileus virginianus) in the northeastern lower peninsula of Michigan (Schmitt et al., 1997). The area where tuberculosis is endemic in deer involves the adjoining corners of Alpena, Alcona, Montmorency, and Oscoda counties and a special Deer Management Unit was formed (DMU 452) to manage this area separately from the rest of the state (Fig. 1). The discovery of endemic tuberculosis in deer coupled with the wide host range of $M$. bovis provided the impetus for a survey of other wild species present in the area. Wildlife species selected for inclusion in the study (which is ongoing) were those carnivorous or omnivorous mammalian species present in DMU 452 and whose population density was sufficient to allow collection. Species included in this survey were the opossum (Didelphis virginiana), raccoon (Procyon lotor), coyote (Canis latrans), red fox (Vulpes vulpes), bobcat (Felis rufus), and badger (Taxidea taxus).

Michigan Department of Natural Resources (MDNR; Lansing, Michigan, USA) personnel picked up the carcasses of carnivores and omnivores killed by vehicle collisions and solicited carcasses from hunters and trappers. Included in the survey were all carnivores and omnivores obtained by the MDNR, which died either in DMU 452 or in the $2-\mathrm{km}$ zone surrounding this area. MDNR personnel recorded the location and origin of each carcass prior to freezing and transport to a MDNR biologist or veterinarian who determine the sex and age. Ages were categorized as adult or juvenile based on the presence of adult or juvenile dentition. Carcasses were then necropsied by pathologists at the Animal Health Diagnostic Laboratory (AHDL; Michigan State University, East Lansing, Michigan, USA). Visible lesions if present and the parotid, 


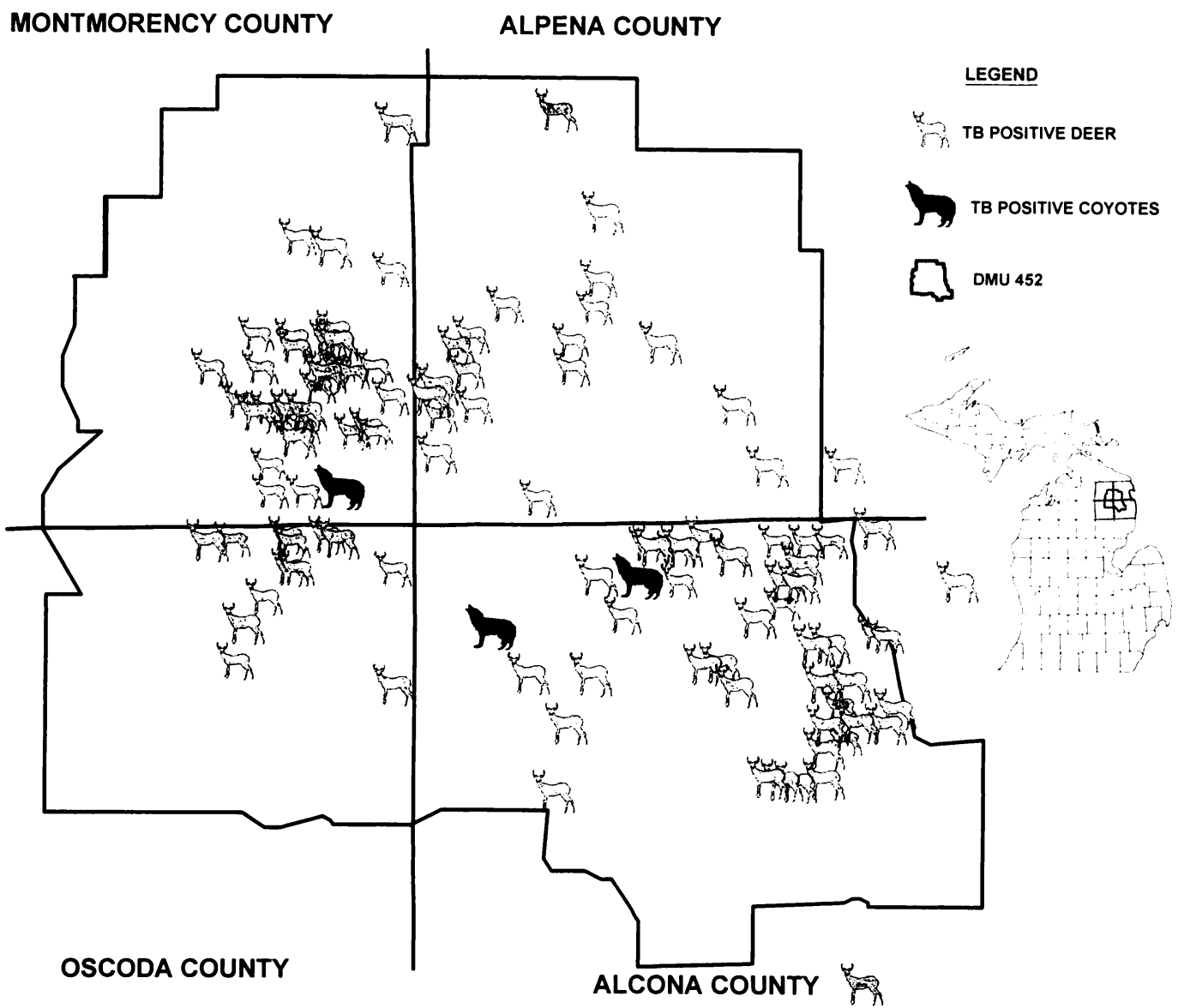

FIGURE 1. Location of Mycobacterium bovis infected coyote and white-tailed deer in Michigan, 1996.

mandibular, medial retropharyngeal, bronchial, mediastinal, and mesenteric lymph nodes of all animals in addition to any visible lesions were collected for histologic examination and culture. Portions of all lesions and lymph nodes were fixed in $10 \%$ neutral buffered formalin for histopathology. All tissue sections were stained with routine hematoxylin and eosin and the Ziehl-Neelsen method for acid-fast staining prior to histopathologic examination at the AHDL (Prophet et al., 1992). The remaining tissues were pooled into one sample per animal then sent on ice packs to the National Veterinary Services Laboratories (NVSL; Ames, Iowa, USA) for mycobacterial isolation and identification as previously described (Schmitt et al., 1997).

Restriction fragment length polymor- phism (RFLP) analysis was conducted to compare the DNA fingerprint of all $M$. bovis isolates from wildlife sampled in this survey with $M$. bovis isolated previously from white-tailed deer in the same area. The conditions and methods used for RFLP analysis were as previously described (Whipple et al., 1997).

Sixty-two carcasses were collected and examined grossly for tuberculosis. All animals were grossly normal on necropsy (one juvenile and 14 adult coyotes, three juvenile and eight adult opossums, three juvenile and 25 adult raccoons, three juvenile and two adult red foxes, two adult badgers, and one adult bobcat). Due to a variety of reasons (change in examination protocol, poor condition of carcasses, lack of available laboratory personnel) not all of 
the animals were examined histologically and tissues cultured. Of the 41 animals examined histologically ( 12 coyotes, seven opossums, 16 raccoons, four red foxes, one badger, and one bobcat), 40 had no lesions suggestive of tuberculosis. The mesenteric lymph nodes of one adult coyote contained multiple necrotic foci, which were partially mineralized. Acid-fast organisms were not observed and mycobacteria were not isolated from this coyote. The cause of the necrotic, mineralized foci could not be determined. Mycobacterial cultures also were negative in six additional coyotes, six opossums, 16 raccoons, four red foxes, and one bobcat.

Mycobacterium bovis was cultured from three female adult coyotes from DMU 452. Two coyotes were collected from Alcona county $\left(44^{\circ} 50^{\prime} \mathrm{N}, 83^{\circ} 44^{\prime} \mathrm{W} ; 44^{\circ} 48^{\prime} \mathrm{N}\right.$, $\left.83^{\circ} 50^{\prime} \mathrm{W}\right)$ and one from Montmorency county $\left(44^{\circ} 53^{\prime} \mathrm{N}, 83^{\circ} 56^{\prime} \mathrm{W}\right)$ on 16 November 1996, 15 November 1997, and 23 November 1997, respectively (Fig. 1). All carcasses were grossly normal. No microscopic lesions were seen during histologic examination of the mesenteric, mediastinal, and cranial lymph nodes; all acid-fast stained sections were negative for acid-fast organisms. Mycobacterium bovis was cultured from individual animal samples pooled from the mesenteric, mediastinal, and cranial lymph nodes of each animal.

The finding of $M$. bovis in free-ranging coyotes is not unprecedented. Mycobacterium bovis was cultured from one of 23 free-ranging coyotes collected near a $M$. bovis infected captive elk herd in Montana (Rhyan et al., 1995a). No gross or microscopic lesions where observed in this coyote. Restriction fragment length polymorphism analysis indicated that this isolate was indistinguishable from $M$. bovis isolated from captive elk (Cervus elaphus nelsoni) located nearby (Whipple et al., 1997) and there was evidence suggesting that the fence surrounding the captive elk herd had been penetrated by coyotes (Rhyan et al., 1995b).

Restriction fragment length polymor- phism analysis has been completed for one of the Michigan coyote isolates. The RFLP patterns for the $M$. bovis isolate from this coyote were identical to the patterns for isolates from three white-tailed deer from DMU 452 that were used for comparison when DNA was digested with PvuII and hybridized with the 123-bp IS6110 probe and when DNA was digested with $A l u I$ and hybridized with the DR probe (data not shown). When DNA was digested PvuII and hybridized with the 445-bp IS6110 probe, two of the three deer isolates had RFLP patterns identical to the coyote isolate. The isolate from one deer had an extra band that was not present in the RFLP pattern of the other isolates (data not shown).

Restriction fragment length polymorphism analysis is becoming a more commonly used technique to compare the genetic relatedness of $M$. bovis isolates (Collins et al., 1993, 1994). The similarity in RFLP patterns between the M. bovis isolates from the coyote and deer provides strong evidence of a link between the cases. In addition, numerous deer infected with $M$. bovis have been harvested in close proximity to these coyotes. There are several reports of $M$. bovis infection in carnivores attributed to the consumption of tuberculous meat (Francis, 1958; Little et al., 1982). In view of this evidence, the most likely source of infection for these coyotes was through the consumption of tuberculous white-tailed deer.

There are several reports of mycobacterial isolation in carnivores without visible lesions (Francis, 1958; Little et al., 1982; Lugton et al., 1997; Rhyan et al., 1995a). In cases with visible lesions, tuberculosis in carnivores is thought to be most often a chronic disease characterized by caseous reaction and fibrous encapsulation suggesting that carnivores are relatively resistant to tuberculosis (Francis, 1958). However, one report found two free-ranging wolves (Canis lupus) with numerous tubercles in the intestinal tract and the authors attributed the deaths of these ani- 
mals to emaciation secondary to tuberculosis (Carbyn, 1982).

The distribution and state of lesions present in an infected animal give some indication of a particular species ability to act as a reservoir host since successful disease transmission requires excretion of the infectious agent from the host. While most mammalian species are susceptible to bovine tuberculosis (Francis, 1958), only a few are thought to be reservoirs of $M$. bovis. Among non-ruminant wildlife, brushtail possums (Trichosurus vulpecula) and ferrets (Mustela furo) in New Zealand and European badgers (Meles meles) in England and Ireland are suspected to be reservoir hosts for bovine tuberculosis (Nolan and Wilesmith, 1994; Patterson et al., 1995; Sauter and Morris, 1995). This is based on extensive lesion development containing enormous numbers of bacilli and demonstrable excretion of $M$. bovis (Gallagher et al., 1976; Jackson et al., 1995; Morris et al., 1994; Nolan and Wilesmith, 1994; Ragg et al., 1995) noted in these species. The lack of gross or microscopic lesions in the coyotes from Michigan indicate that these animals were either infected recently (sufficient time had not elapsed to allow the development of lesions) or that the development of discernable lesions was impaired due to the relative resistance of these coyotes to tuberculosis. Although it is currently thought that coyotes in Michigan do not serve as a reservoir for tuberculosis, studies are continuing.

We thank N. H. Lehman and R. L. Lyon for technical assistance with RFLP analysis, the MDNR, AHDL, and USDA personnel who helped with the carnivore/omnivore survey, and the hunters who participated in the surveys. This work was partially supported by the Federal Aid in Wildlife Restoration Act under Michigan Pittman-Robertson Project W-127-R.

\section{LITERATURE CITED}

CarbyN, L. N., 1982. Incidence of disease and its potential role in the population dynamics of wolves in Riding Mountain National Park, Manitoba. In Wolves of the world: Perspectives of behavior, ecology, and conseration. F. II. Harrington and P. C. Paquet (eds.). Noyes Publications, Park Ridge, New Jersey, pp. 106-116.

Collins, D. E., S. K. Erasmlist, D. M. StepheNS, G. F. YATES, AND G. W. DE LISIE. 1993. INNA fingerprinting of Mycobacterium bovis strains by restriction fragment analysis and hybridization with insertion fragments IS1081 and IS6110. Journal of Clinical Microbiology 31: 1143-1147. , A. J. RADFORD, (. W. DE LISLE, AND H. BILL.MAN-JACOBE. 1994. Diagnosis and epidemiology of bovine tuberculosis using molecular biological techniques. Veterinary Microbiology 40: 8:3-94.

FravCIS, J. 1958. Tuberculosis in animals and man. Cassell and Company, London, UK, 357 pp.

Gallagher, J., R. H. Muirhead, and K. J. BukN. 1976. Tuberculosis in wild badgers (Meles meles) in Gloncestershire: Pathology. Veterinary Record 98: 9-14.

JACKSON, R., M. M. COOKE, J. D. (OLEMAN, AND R. S. MORRIS. 1995. Naturally occurring tuberculosis caused by Mycobacterium botis in brushtail possums (Trichosurus vulpecula): I. An epidemiological analysis of lesion distribution. New Zealand Veterinary Journal 43: 306-314.

LitTle, T. W. A., C. SWAN, H. V. ThOMPSON, ANi) J. W. WILESMITH. 1982. Bovine tuberculosis in domestic and wild mammals in an area of Dorset. III. The prevalence of tuberculosis in mammals other than badgers and cattle. Journal of Hygiene 89: 225-234.

Lugton, I. W., G. WOBESER, R. S. MORRIS, AND P. CALEY. 1997. Epidemiology of Mycobacterium bovis infection in feral ferrets (Mustela furo) in New Zealand: I. Pathology and diagnosis. New Zealand Veterinary Journal 45: 1140-1150.

Morris, R. S., D. U. PFEIFFER, AND R. JACKSON. 1994. The epidemiology of Mycobacterium bovis infections. Veterinary Microbiology 40: 15.3-177.

NOLAN, A., AND J. W. WILESMITH. 1994. Tuberculosis in badgers (Meles meles). Veterinary Microbiology 40: 179-191.

Patterson, B. M., R. S. Morris, J. Weston, aNd P. E. Cowan. 1995. Foraging and denning patterns of brushtail possums, and their possible relationship to contact with cattle and the transmission of bovine tuberculosis. New Zealand Veterinary Journal 43: 281-288.

Prophet, E. B., B. Millis, J. B. Arrington, ANd L. H. SOBIN (editors). 1992. Laboratory methods in histotechnology. Armed Forces Institute of Pathology, American Registry of Pathology, Washington, D.C., 279 pp.

RaGG, J. R., K. A. Waldrup, ANd H. Moller. 1995. The distribution of gross lesions of tuberculosis caused by Mycobacterium bovis in feral ferrets 
(Mustela furo) from Otago, New Zealand. New Zealand Veterinary Journal 43: 338-341.

Rhyan, J. C., K. Aune, R. Clarke, R. Meyer, C. SIROKY, AND L. STACKHOUSE. 1995a. Discovery of bovine tuberculosis in free-ranging mule deer and results of continued wildlife surveillance in the area. In Proceedings of the Veterinary Epidemiology and Economics Symposium, United States Department of Agriculture, Animal and Plant Health Inspection Service, Centers for Epidemiology and Animal Health, Fort Collins, Colorado, pp. 1B2-1B4.

Rhyai, J. C., K. Alne, B. Hood, R. Clarke, J. PayElR, J. JaRNagiN, AND L. StaCkHOUSE. 1995b. Bovine tuberculosis in a free-ranging mule deer (Odocoileus hemionus) from Montana. Journal of Wildlife Diseases 31: 432-43.5.

SALTER, C. M., AND R. S. MORRIS. 1995. Behavioral studies on the potential for direct transmission of tuberculosis from feral ferrets (Mustela furo) and possums (Trichosurus vulpecula) to farm livestock. New Zealand Veterinary Journal 43: 294300.

SChMitT, S. M., S. D. Fitzgerald, T. M. CoOley, C. S. Bruning-FanN, L. Sullivan, D. Berry, T. Carlson, R. B. Minnis, J. B. Payeur, and J. SIKARSKIE. 1997. Bovine tuberculosis in freeranging white-tailed deer in Michigan. Journal of Wildlife Diseases 33: 749-758.

Whipple, D. L., P. R. Clarke, J. L. Jarnagin, aNd J. B. Payeur. 1997. Restriction fragment length polymorphism analysis of Mycobacterium bovis isolates from captive and free-ranging animals. Journal of Veterinary Diagnostic Investigation 9: 381-386.

Received for publication 22 September 1997. 